tles were kept in cages and were fed egg masses, which they consumed entirely. No Hymenopterous parasites were reared from larvae or eggs.

President Arthur Gibson: The final paper in the series is by Mr. E. P. Felt.

\title{
THE EUROPEAN CORN BORER IN NEW YORK STATE ${ }^{1}$
}

By E. P. Felt, State Entomologist, Albany, N. $Y$.

The exceptionally severe and wide spread injury by the corn ear worm, Chloridea obsoleta Fabr., has been particularly unfortunate in that it has attracted general attention to a passing phenomenon and thus in considerable measure obscured a really serious problem.

It happens that the European Corn Borer, Pyrausta nubilalis Hubn., has as yet caused relatively little damage in New York State, though there has been appreciable injury to comparatively small plantings. The development of the last few years make it impossible to be certain as to the cause for this comparative immunity. The exceptionally thorough and general clean up in the eastern infested area in the spring of 1919 presumably had an important effect upon the abundance of the borers and even yet the pest is not numerous in that section, a fifteen per-cent stalk infestation being near the maximum. This work was on an exterminative basis, consequently no checks were left.

There was in the western part of New York State a thorough clean up during the fall of 1920 and the spring of 1921 by the Federal Government in the more badly infested section, centering on Silver Creek. Examinations and comparisons the past summer showed little difference between the cleaned up areas and the conditions on the nearby Indian Reservation where a forty per-cent stalk infestation was not difficult to find. There is no question but what the clean up destroyed hosts of borers. It is possible that climatic conditions were exceptionally favorable and enabled the few remaining insects to transform and deposit a maximum number of eggs and thus offset in considerable measure the beneficent results which should follow general clean up work. It has been suggested that the operations may have been nullified to a considerable extent by moths drifting from another badly infested area. This must be considered simply as a possibility and as yet not even the probability has been established.

\footnotetext{
1Some of the data given in this paper have been secured by the writer in his capacity as Collaborator, Bureau of Entomology, U. S. Department of Agriculture.
} 
The spread in New York State has been moderate, approximately a six mile extension on all boundaries, though the increase in the known infested area has been somewhat greater, due presumably to the difficulty of establishing the actual limits each season. There are now nearly 5000 square miles infested in New York State.

The similarity of conditions last summer in the infested areas of eastern and western New York and Ontario, Can., is further shown by the finding of the first pupa in the field at Scotia and Port Stanley May 30 th, the first moths at Scotia and Silver Creek June 16th, an empty pupal case at Port Stanley on the same date, and the first egg mass at Scotia June 16th, at Silver Creek June 22d and at Port Stanley June 25th. Furthermore, in each of these localities, there was a partial, though very small, second generation.

The season of 1921 showed a marked increase in injury in the badly infested area in Ontario, and since climatic and agricultural conditions in that section and in eastern and western New York, particularly the latter, are very nearly identical, it may be that this development is prognostic for the New York areas. Here again, we are venturing into the realm of theory and this latter, when applied to the interpretation of conditions in eastern New York as compared with those in eastern Massachusetts has not always been entirely satisfactory.

It is certain that in portions of both the eastern and western infested areas in New York State, there are enough borers so that their progeny under exceptionally favorable conditions, such as appear to have obtained last year, might cause very serious losses, particularly to the early planted sweet and Flint corn. This is a possibility, which.by some might be construed as a probability.

The close studies of the corn borer under New York conditions for the past three seasons have failed to show habitual breeding of this insect in any plant except corn and the occurrence of the borers in the stems of weeds, etc. has been restricted to plants in the near vicinity of corn. This relative freedom of other plants from infestation has been reflected in the modified quarantine recently promulgated and restricted in its application to corn, broom corn, all sorghums and sudan grass. There is ground for fearing a more general infestation following an increase in the relative number of the borers and should this occur, it would inevitably mean an extension of quarantine measures to other plants and in these latter there would probably be several important garden products.

It is obvious that national and state agencies cannot indefinitely continue to clean up the constantly increasing infested areas and it 
therefore follows that repressive measures, which appear practicable to the farmer must be devised or serious losses may follow. The most promising of these were outlined at the somewhat recent Sandusky -St. Thomas conference and need not be discussed in this connection.

The corn ear worm situation and the relatively slight injury from European Corn Borer has resulted in comparatively little attention being given to the latter in New York State, in spite of its potential importance. It has seemed to the writer that conditions entirely justified the pointing out of the possibility, if not probability, of serious injury following a continuation of the corn borer conditions outlined above and the calling attention to the fact, that in the event of such developments, there would probably be a restoration and enforcement of the quarantine as originally promulgated. An effort is being made to interest the corn growers along these lines and in view of the fact that our badly infested corn, mostly the early planted corn, occupies a comparatively small proportion of the acreage, it seems entirely practicable and under present conditions desirable to emphasize the need of giving special attention to that part of the crop, though it would naturally follow that all corn fodder in infested areas would be worked up a little more carefully than has previously been the case.

A redeeming feature of the situation is found in the fact that infestation by the European Corn Borer is rarely uniform throughout the territory. There are marked variations. Many of these presumably can be explained by the difference between early and late planting and to some extent by variations in nearby sources of infestation. There is still great need of ascertaining the limitations of this insect under field conditions so that they may be used to advantage in ordinary farm practice.

Mr. T. J. HEAdLEE: I would like to ask concerning control measures? If the individual farmer should practice the best combination of cultural methods that we have heard this afternoon, would he obtain freedom or approximate freedom the following year, though his neighbors did nothing to control the insect?

Mr. G. J. SPENCER: I would say no. An investigation was conducted on a badly infested field last year. The field was gone over with a potato digger. It was also gone over with forks, and was handpicked, and yet the infestation this year was about the same as the previous year.

Mr. E. P. FELT: Was this in the badly infested area?

Mr. G. J. SPENCER: Right in the middle of the badly infested arearight alongside of it. 
There was one instance where it was effective. It may have been due to slightly later planting. It was an isolated field hedged in on two sides by woods, and this field infested last year was this year almost free, due I think to the lateness of planting; although the man did carry out an extensive cleanup campaign last fall.

MR. W. R. WALTON: I would like to ask Mr. Spencer if I may whether he finds that the physical condition of the soil affects migration of the larvae? Does he not find that migration is less in heavy soil than in light soil?

Mr. G. J. Spencer: I will refer that to Mr. Crawford.

Mr. H. G. CRAWFORD: In connection with this point I might say that we carried out a series of experiments, burying ten stalks in loose bundles and single layers, at depths of six inches, throughout the season. The chief governing factor in the early season in the rate of larval emergence from various buried stalks was the moisture of the soil. They came up through very heavy clay soil to all practical purposes at the same rate of speed as they came up through sand. In fact, sand soil is the most retentive of larvae of any soil used in the experiments. Some of these experiments were put in between the fourth and the eleventh of September, so there was no temperature factor slowing them up in the sand at least during the first part of the season.

MR. W. R. WALTON: It seems curious that yours seem to be directly opposite to the results which we secured in similar experiments.

Mr. H. G. CRAwFord: In regard to the matter of control for the individual farmer-for effective results it has to be done on a community basis. However, there is the point to bear in mind that the early planted corn is very severely infested and ruined, in a case of sweet cornone hundred per cent. loss. In the same vicinity the late planted corn, though fairly heavily infested, is not severely damaged, and the individual farmer could thus stop severe loss comparatively easily. In our efforts next year to get a group of the farmers to follow as many of our suggestions as possible, we are going to lay particular emphasis on putting corn in as late as is safe in the community. If they put it in as late as they feel, as practical growers, is safe, it will cut down the loss; though we will still be carrying infestations up to sixty, seventy and in some cases eighty per cent.

Mr. E. P. Felt: Has Mr. Crawford any definite information, or an approximate idea of the relative area in the badly infested section, which was severely damaged by corn borer? I asked that question last fall. Has he an answer now?

Mr. H. G. Crawford: I have not. It would involve the study of every corn field involved, as one field will be less than twenty-five 
per cent. infested and the next one will be sixty-five per cent. loss. This makes the determination of the general dollars and cents loss almost an impossibility unless one looks at them and canvasses every field oneself. An untrained man who has not really worked over a set of cobs and can tell the percentage of kernels involved and the stalk loss associated therewith, cannot give valid information. I am sorry, Dr. Felt, that it is impossible to give you the information.

President Arthur Gibson: The next paper is by $R$. C. Treherne.

\section{THE ONION MAGGOT IN BRITISH COLUMBIA UNDER IRRIGATED CONDITIONS}

By R. C. Treherne, Ottawa, Can.

(Withdrawn for publication in the 52d Report of the Entomological Society of Ontario.)

President Arthur Gibson: The next paper is by L. Caesar.

\section{THE CABBAGE ROOT MAGGOT}

By L. CaEsar, Guelph, Canada

(Withdrawn for publication in the 52d Report of the Entomological Society of Ontario.)

President Arthut Gibson: The next paper is by Glenn W. Herrick.

\section{THE LIFE HISTORY, HABITS AND INJURIES OF THE MAPLE CASE-BEARER}

By GLenN W. Herrick, Ithaca, $N . Y$.

(Withdrawn for publication elsewhere.)

President Arthur Gibson: The next paper is by J. W. McColloch.

\section{LONGEVITY OF THE LARVAL STAGE OF THE CADELLE ${ }^{1}$}

By J. W. McColloch, Associate Entomologist, Kansas Agricultural Experiment Station

The Cadelle (Tenebroides mauritanicus Linn.) in spite of its importance as a pest of stored grain and grain products has not been the subject of any extensive life history studies. Curtis ${ }^{2}$ (p. 332) reports the rearing of a beetle by Kirkup from a Spanish almond. The larva lived fifteen months in addition to the period it had been in existence before its discovery and the beetle remained alive for 21 months.

\footnotetext{
'Contribution No, 72 from the Entomological Laboratory, Kansas State Agricultural College and Experiment Station.

'Curtis, John. 1883 Farm Insects. John Van Voorst, London.
} 